\title{
The role of neutralizing antibodies in prevention of HIV-1 infection: what can we learn from the mother-to-child transmission context?
}

\author{
Martine Braibant ${ }^{1 *}$ and Francis Barin ${ }^{1,2}$
}

\begin{abstract}
In most viral infections, protection through existing vaccines is linked to the presence of vaccine-induced neutralizing antibodies (NAbs). However, more than 30 years after the identification of AIDS, the design of an immunogen able to induce antibodies that would neutralize the highly diverse HIV-1 variants remains one of the most puzzling challenges of the human microbiology. The role of antibodies in protection against HIV-1 can be studied in a natural situation that is the mother-to-child transmission (MTCT) context. Indeed, at least at the end of pregnancy, maternal antibodies of the IgG class are passively transferred to the fetus protecting the neonate from new infections during the first weeks or months of life. During the last few years, strong data, presented in this review, have suggested that some NAbs might confer protection toward neonatal HIV-1 infection. In cases of transmission, it has been shown that the viral population that is transmitted from the mother to the infant is usually homogeneous, genetically restricted and resistant to the maternal HIV-1-specific antibodies. Although the breath of neutralization was not associated with protection, it has not been excluded that NAbs toward specific HIV-1 strains might be associated with a lower rate of MTCT. A better identification of the antibody specificities that could mediate protection toward MTCT of HIV-1 would provide important insights into the antibody responses that would be useful for vaccine development. The most convincing data suggesting that NAbs migh confer protection against HIV-1 infection have been obtained by experiments of passive immunization of newborn macaques with the first generation of human monoclonal broadly neutralizing antibodies (HuMoNAbs). However, these studies, which included only a few selected subtype B challenge viruses, provide data limited to protection against a very restricted number of isolates and therefore have limitations in addressing the hypervariability of HIV-1. The recent identification of highly potent second-generation cross-clade HuMoNAbs provides a new opportunity to evaluate the efficacy of passive immunization to prevent MTCT of HIV-1.
\end{abstract}

Keywords: HIV-1, Neutralizing antibodies, Mother-to-child transmission, Preventive vaccine, Passive immunization, Immunoprophylaxis

\section{Review}

Introduction

UNAIDS estimates that there were 34.0 million people living with the human immunodeficiency virus (HIV) at the end of 2011. The development of a safe, effective, preventive HIV vaccine remains among the highest global health priorities. Most vaccines that successfully control viral diseases induce the production of neutralizing

\footnotetext{
*Correspondence: braibant@med.univ-tours.fr

'Université François-Rabelais, UFR Médecine, Inserm U966 10 bld Tonnellé, cedex, 37032 Tours, France

Full list of author information is available at the end of the article
}

antibodies (NAbs) that prevent infection. In the case of HIV-1, a key element for NAbs to be effective in preventing infection is their capacity to neutralize the highly diverse circulating HIV-1 variants, which can differ by more than $30 \%$ in the sequences of their envelope glycoproteins. Encouragement for the development of a NAbbased anti-HIV-1 vaccine was provided by successful passive immunization studies in macaque models showing that broadly human monoclonal NAbs administered orally, vaginally or intravenously could prevent the acquisition of infection [1-10]. Despite the fact that in some of these experiments, the viral strain used for

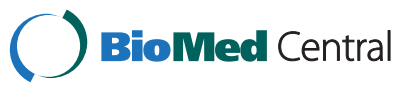


challenge was particularly sensitive to neutralization by the passively administered NAbs, these results provided the proof-of-concept that antibodies can block HIV-1 infection. Unfortunately, the capability of vaccine candidates to induce NAbs has turned out to be extremely complex and disappointing. First attempts to develop antibody-based anti-HIV-1 vaccines in man involved recombinant protein immunogens based on monomeric forms of the surface-exposed gp120 component of the envelope glycoprotein (AIDSVAX gp120 B/B and B/E) [11-13]. High levels of antigen-specific antibodies were induced in human vaccinees but failed to neutralize most primary isolates and did not confer protection [14-17]. More recently, the RV144 vaccine trial based on a primeboost regimen consisting of a recombinant canarypox vector prime (ALVAC-HIV) and gp120 protein boost (AIDSVAX gp120 B/E), showed only moderate protection in low-incidence heterosexuals [18]. These trials, in a real life situation, have indicated the limitations of animal model studies that used only a few selected challenge viral strains. They also highlighted the probable need to develop more sophisticated envelope immunogens. For this, lessons from studies aiming at dissecting the antibody response during natural infection might be particularly useful. It has been shown recently that broadly NAbs, developed after several years of infection by some HIV-1 infected patients, require a high level a somatic mutations to become broad and potent [19-24]. This suggests that an effective vaccine may require a combination of various envelopes to direct B-cell responses through multiple rounds of antibody maturation and mutation process [25]. Another key question for vaccine development is the identification of correlates of protection. Indeed, the specificity and magnitude of the NAbs response required to confer protection against HIV-1 transmission in humans are still unclear, and progress in this field is a key step on the road to an effective HIV-1 vaccine.

\section{Mother-to-child transmission: a model to identify correlates of protection}

Mother-to-child transmission (MTCT) of HIV-1 is currently the principal cause of HIV infections in children. Whereas access of HIV pregnant women to antiretroviral therapy has increased significantly, HIV infection in children remains a major concern. In 2011, an estimated 330,000 children were newly infected with HIV (UNAIDS). Without any antiretroviral treatment, MTCT rate of HIV-1 is around 30 to $40 \%$ and occurs mainly at three stages: in utero during pregnancy (5-10\%), perinatally at the time of labor and delivery (15-20\%), and postpartum through breastfeeding (10-15\%) [26-29] (Figure 1). This contrasts with a much lower rate of MTCT of HIV-2 which, in absence of antiretroviral treatment, ranges from $0 \%$ to $4 \%$ only [30-34]. Despite the high transmission rates of HIV-1,

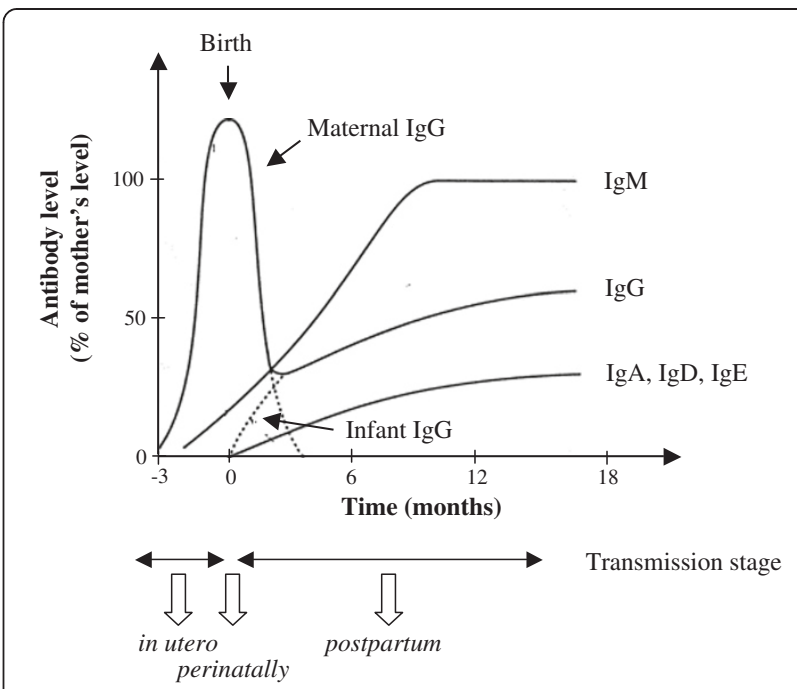

Figure 1 Infant antibody levels over the three possible stages (in utero, perinatally or postpartum) of mother-to-child transmission of HIV-1. During pregnancy, maternal IgG are transmitted to the fetus across the placenta, reaching normal or somewhat exceeding adult levels at term. After birth, the lgG transferred from the mother disappear progressively, while the amount of IgG being produced by the infant continues to increase. In contrast, the placenta is relatively impermeable to $\mathrm{lg}$ of other classes, levels of which are therefore very low in the newborn.

a large number of children exposed to HIV-1 do not become infected. Several maternal factors, including low $\mathrm{CD}^{+}{ }^{+} \mathrm{T}$-cells counts and high viral loads are associated with an increasing risk of HIV-1 MTCT [35]. The lower plasma viral load in HIV-2 infected patients, compared to HIV-1 infected patients, may account for the lower MTCT risk for HIV-2 [33,34,36-40].

The role of maternal immune response in limiting HIV-1 transmission to the infant is still unclear. The placenta is relatively impermeable to IgA and IgM, levels of which are therefore very low in the newborn. In contrast, maternal IgG are transported over the placenta by an active process mediated by the FcRn receptor [41]. The timing of maternal IgG passage across the placenta during pregnancy was addressed in several studies (for a review see [42]). During the first trimester, very little IgG is transmitted to the fetus, but in the second trimester, the fetal IgG concentration increases from approximately $10 \%$ of the maternal concentration at 17-22 weeks of gestation to $50 \%$ at $28-32$ weeks [41,43-45]. During the third trimester, fetal IgG levels continue to rise, reaching normal or somewhat exceeding adult levels at term [45-50] (Figure 1). It was illustrated recently in the HIV-1 context in a study that showed that the envelope binding antibody titers were strongly correlated and similar between mothers and their corresponding infants [51]. MTCT constitutes therefore an attractive model to explore the putative protecting role of passively acquired HIV-specific IgG 
against HIV acquisition. In the absence of data on the putative role of NAbs in prevention of MTCT of HIV-2, this review will focus on HIV-1 infection that has been the subject of intensive investigations.

\section{Selective transmission of HIV-1 variants from mothers to infants}

The first molecular studies of env sequences diversity issued from infected individuals, adults as well as children, have shown that most of acute/recent infections are characterized by the presence of a highly homogenous genetically-restricted virus population in contrast to the high genetic diversity observed several years later at time of chronic infection [52-62]. These observations led rapidly to the assumption of a substantial bottleneck in virus transmission (Figure 2A). Recently, the use of single genome amplification (SGA) of HIV-1 plasma viral RNA obtained from acutely infected adult individuals, allowed the identification of transmitted/early founder viruses, and the precise estimation of their diversity [63-67]. These studies showed evidence of infection by a single virus in $\sim 80 \%$ of heterosexuals and $\sim 60 \%$ of HIV- infected men who have sex with men $[63,64,66,67]$. In contrast, the frequency of multiple variants transmission was found to be higher among intravenous (IV) drug users $(\sim 60 \%)$, including one subject who was infected by at least 16 variants [65]. The high frequency of mutiplevariants transmission in IV drug users could be due to the absence of a mucosal barrier to virus transmission and higher virus inocula. To date, such large studies have not been conducted on samples from children born to infected mothers. However this question has been considered using different molecular approaches (Table 1) (Figure 2B) [61,68-89]. Data vary from one study to another but all together, comparing the viral population in mother-child pairs, they showed a homogeneous genetically-restricted population in the majority of infected infants (156 of 235; table I), suggesting a selective transmission of some viral variants during MTCT (Figure 2B). The lack of consensus among these studies may be due to the fact that many studies compared only a limited number of mother-child pairs and did not address the route of transmission (in utero, perinatally or postpartum through early breasfeeding). In

A

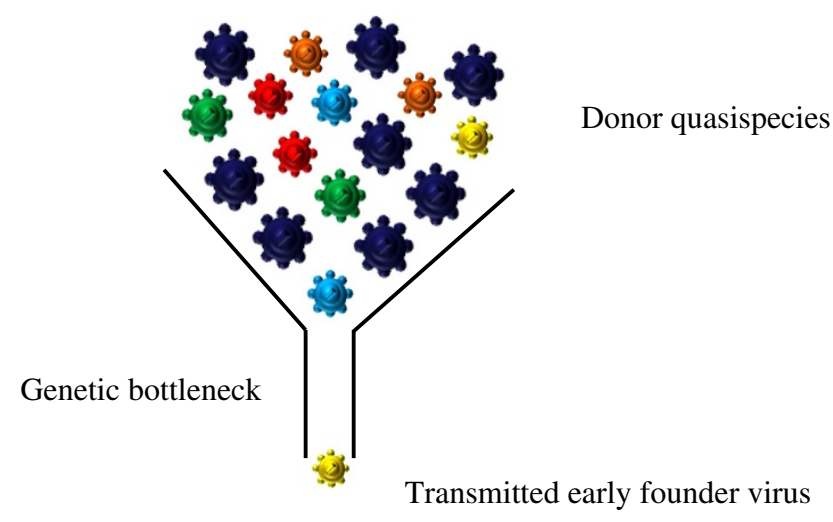

B
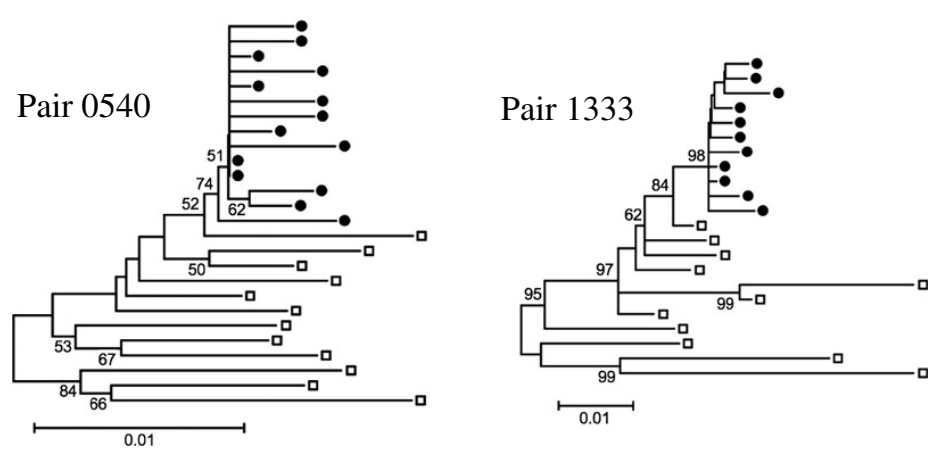

Figure 2 Selective transmission of HIV-1. A. The quasispecies of the chronically infected donor is usually composed of a major viral population (dark blue virions), as well as numerous other minor variants. One of these minor variants (yellow virion) successfully crosses the mucosal barrier to generate the infection of the recipient. B. The neighbor-joining trees of HIV-1 env gp120 nucleotide sequences issued from two mother-infant pairs show the transmission of a single maternal viral variant [85]. Bootstrap values are expressed as percentages per 1000 replicates. Only bootstrap values $>50 \%$ are indicated. Horizontal branch lengths are drawn to scale, with the black bar denoting $1 \%$ divergence. Each symbol denotes a single env sequence; $\square$, maternal sequence; $\bullet$, infant sequence. 
Table 1 Studies of the viral population of HIV-1 infected infants

\begin{tabular}{|c|c|c|c|c|c|}
\hline \multicolumn{3}{|c|}{ Infant samples } & \multirow[b]{2}{*}{ Infection route } & \multirow{2}{*}{$\begin{array}{l}\text { Homo-/heterogeneous } \\
\text { population ratio }\end{array}$} & \multirow[b]{2}{*}{ References } \\
\hline Nature & Collection time* & $\begin{array}{l}\text { Amplified env } \\
\text { region }\end{array}$ & & & \\
\hline PBMCs & 2 to 4 months & V3 and V4-V5 & Unspecified & $3 / 0$ & {$[61]$} \\
\hline PBMCs & Unspecified & V3 and V4-V5 & Unspecified & $4 / 0$ & {$[68]$} \\
\hline PBMCs and serum & 0 to 4 months & V3 & $1 \mathrm{IU}, 9$ unknown & $8(1 \mathrm{IU}) / 2$ & [69] \\
\hline Serum & At birth & V3 & $1 \mathrm{IU}$ & $1 / 0$ & [70] \\
\hline PBMCs & 0 to 12.5 months & V3 & $1 \mathrm{IU}, 4$ unknown & $2 / 3(1 \mathrm{IU})$ & [71] \\
\hline PBMCs & 2 days to 7 weeks & V1-V2-C2 & Unspecified & $1 / 2$ & [72] \\
\hline PBMCs & 1 week to 34 months & V3 & Unspecified & $7 / 0$ & [73] \\
\hline PBMCs & 5 days to 1.5 months & V3 & Probably 1 PN, 3 IU & $1(\mathrm{PN}) / 3(\mathrm{IU})$ & [74] \\
\hline PBMCs and plasma & 2 to 40 days & $\mathrm{C} 2-\mathrm{V} 3$ & Unspecified & $3 / 1$ & [75] \\
\hline PBMCs & 1 month & V3 & Unspecified & $13 / 4$ & [76] \\
\hline Plasma & 48 hours or 2 to 6 weeks & V3-V5 & $9 \mathrm{PN}, 14 \mathrm{IU}$ & 17 (7 PN, $10 \mathrm{IU}) / 6$ (2 PN, $4 \mathrm{IU})$ & {$[77]$} \\
\hline PBMCs & 0 or 2 to 6 months & $\mathrm{C} 2-\mathrm{V} 4$ & 3 PN or early PP, $1 \mathrm{IU}$ & $3(2 \mathrm{PN}, 1 \mathrm{IU}) / 1$ & [78] \\
\hline PBMCs & 0 or 6 weeks & V1-V4 & 7 PN or early PP, $6 \mathrm{IU}$ & $6(2 \mathrm{IU}, 4 \mathrm{PN}) / 7(4 \mathrm{IU}, 3 \mathrm{PN})$ & [79] \\
\hline PBMCs & 48 hours or 2 to 6 weeks & V3-V5 & $7 \mathrm{PN}, 14 \mathrm{IU}$ & 15 (5 PN, 10 IU)/6 (2 PN, 4 IU) & {$[80]$} \\
\hline PBMCs or plasma & 6 weeks & $\mathrm{V} 1-\mathrm{V} 5$ & $8 \mathrm{PN}$ or early PP, $1 \mathrm{IU}, 3 \mathrm{BF}$ & $11 / 1(\mathrm{PN})$ & {$[81]$} \\
\hline PBMCs or cord blood & 0 or 6 to 15 months & V1-V3 & $3 P P, 1 \mathrm{IU}$ & $4 / 0$ & {$[82]$} \\
\hline PBMCs & 4 to 18 months & V1-V5 & Unspecified & $0 / 3$ & [83] \\
\hline Plasma & 0 or 6 weeks & V1-V2 & $23 \mathrm{PN}, 25 \mathrm{IU}$ & $20(6 \mathrm{PN}, 14 \mathrm{IU}) / 28(17 \mathrm{PN}, 11 \mathrm{IU})$ & [84] \\
\hline Plasma & 48 hours or 6 weeks & V1-V5 & $11 \mathrm{PN}, 6 \mathrm{IU}$ & $14(9 \mathrm{PN}, 5 \mathrm{IU}) / 3(2 \mathrm{PN}, 1 \mathrm{IU})$ & {$[85]$} \\
\hline PBMCs & 2 to 4 months & V1-V5 & 6 PN or early PP & $5 / 1$ & {$[86]$} \\
\hline Plasma & 30 to 66 days & V1-V5 & $5 \mathrm{PN}$ & $3 / 2$ & {$[87]$} \\
\hline Plasma & 0 or 6 weeks & V1-V5 & 9 PN or early PP, $10 \mathrm{IU}$ & $13(5 \mathrm{PN}, 8 \mathrm{IU}) / 6$ (4 PN, $2 \mathrm{IU})$ & {$[88]$} \\
\hline \multirow[t]{2}{*}{ Plasma } & 3 or 6 months & complete env & $2 \mathrm{PP}$ & $2 / 0$ & [89] \\
\hline & & & & total: 156/235 & \\
\hline
\end{tabular}

* Time of the first PCR or coculture positive collected sample after birth.

PN: perinatally; IU: in utero; PP: postpartum through breastfeeding.

addition, the ages of the infants at time of sample collection varied considerably among studies.

Focusing on transmission through breastfeeding, three recent studies have shown that there is no or very limited viral compartmentalization between milk and blood, suggesting that breast milk viruses are typical of circulating viruses [90-92]. As with other routes of MTCT, a genetic bottleneck that restrict the number of variants transmitted through breastfeeding to a single or a small number of variants was reported [82].

Several studies examined the molecular characteristics of the envelope glycoproteins of transmitted viruses that might explain the selective process. Two studies of Wolinky's group, in which MTCT route was not defined, reported that the potential N-linked glycosylation site (PNGS) proximal to the first cysteine of the V3 loop (N295) was strikingly absent from the infant's sequence populations but present in the majority of the maternal sequence sets $[61,68]$. This observation has not been found by other investigators [69,70,73,74]. Studies performed on sequences encoding the full-length gp 120 reported shorter variable regions and/or fewer PNGS in clade $\mathrm{A}$ and $\mathrm{C}$ viruses transmitted from mother-to-infant, mainly perinatally or early postpartum $[81,86,88]$. In contrast, we and others did not find altered gp120 length or PNGS number in the clade B and CRF01-AE viruses transmitted perinatally from mothers to their infants $[85,87]$. Interestingly enough, similar observations were reported during or shortly after heterosexual transmission of HIV-1. Transmitted viruses of subtype A and $\mathrm{C}$ showed a more compact and less glycosylated gp120 but this molecular property was not observed for sexually transmitted viruses of clade B $[55,93,94]$. This highlighted potential differences in the biology of the different subtypes, regardless of their transmission mode. Although we did not find shorter gp120s or fewer PNGS in maternally transmitted CRF01-AE viruses, we however found a limited number of PNGS, N301 in V3 and 
N386 in C3, that seemed to be conserved in all infected infants but were not uniformly present in their mothers, suggesting that they may confer an advantage on the virus to be transmitted [85]. By comparing functional properties of pseudotyped viruses expressing envelopes carrying or not N301 and/or N386, we confirmed that these two PNGS may play a role in resistance to autologous sera [95]. Interestingly, the $\mathrm{N}$-linked glycan at position 301 was recently shown to be important for HIV-1 neutralization by several new broad and potent monoclonal NAbs of the PGT series (PGT125-128, PGT130 and PGT131) [96]. Similarly, Moore et al. recently reported in two HIV-1-infected adults the apparition of the N-linked glycan at position 332 targeted by PGT128, through immune escape from earlier strain-specific antibodies [97]. It could be possible that NAbs drive viral selection during MTCT, leading to variants with conserved glycan motifs that would confer a selective advantage.

\section{Neutralizing antibodies: in search of correlates of protection in the MTCT context}

MTCT offers a unique opportunity to explore the putative role of NAbs in restricting or preventing infection, especially when the transmission occurs in presence of high levels of passively acquired maternal IgG, i.e. during the perinatal and early breastfeeding periods. Conflicting results have been obtained concerning the role of maternal NAbs in reducing MTCT of HIV-1. Early studies, each relatively small, showed that non-transmitting mothers had more frequently detected and/or higher titers of autologous NAbs than transmitting mothers, suggesting a role for maternal NAbs in reducing MTCT [98-101]. Supporting this model, a few studies have suggested that transmitted viruses are escape variants resistant to neutralization by maternal antibodies [80-82,102,103]. However, other studies did not confirm these findings [88,89,95,104-106]. The observed discordant results may be due to small sample sizes, disparate maternal and infant sample collection time points, and a lack of identification of the route of transmission in several studies (in utero, in absence or in presence of only low levels of IgG, versus perinatally or early postpartum, in presence of high levels of IgG).

Because transmitted variants were found to be resistant to neutralization by their own mother's plasma in several studies, we previously hypothesized that protective antibodies might be those with a broad neutralizing activity. To test this hypothesis, we conducted three large studies, i.e. two studies in Thailand $[107,108]$, and one study in French patients [109], in which we compared the breadth and levels of NAbs in sera of transmitting and non-transmitting mothers, using panels of heterologous primary isolates of different clades. Our data did not support an association between the breadth of HIV-1 neutralizing activity and a lower rate of MTCT of HIV-1, whether transmission occurred in utero or perinatally (the infants were not breast-fed). Similar results were obtained by others in Kenyan infants of HIV-1 positive mothers [110]. All these data clearly indicate that infants who acquired broad and potent NAbs able to neutralize heterologous HIV-1 variants of different subtypes from their mothers did not show a reduced risk of infection. However, our studies suggested that particular HIV-1 variants might be indicators of NAbs associated with in vivo protection. Indeed we found that NAbs toward a CRF01-AE isolate, MBA, were significantly associated with a lower rate of MTCT in Thailand. Similarly, statistically significant higher frequencies or titers of NAbs toward several strains were observed in non-transmitting mothers in our French study when the clade B-infected mothers or non clade-B-infected mothers were analyzed separately [109]. Collectively, these data suggest that particular HIV-1 variants may provide a measure of protective antibodies depending of the population. These HIV-1 variants may be particular strains on which epitopes targeted by protective NAbs would be particularly well exposed in contrast to those of non-protective antibodies. The identification of these strains would be dependent of the HIV-1 subtype of the studied population suggesting that the neutralizing response specificities might vary between viral subtypes. Conducting large studies on homogeneous populations (in terms of geographical origin, viral clade, maternal viral loads and antiretroviral prophylaxis) to limit confounding viral and/or host factors would be necessary to identify such indicator strains.

The targeted epitope(s) of the neutralizing response associated with protection was not explored in studies cited above. To date, only one recent study conducted in a cohort of South African patients addressed this question by focusing on the putative role of maternal gp41-specific antibodies passively transferred to newborns [111]. An association of antibodies to the membrane-proximal external region (MPER) of gp41 with virus neutralization and protection was reported. This observation needs to be confirmed by other studies. More particularly it should be extended to other important conserved epitopes using various techniques, such as serum absorption with recombinant Env proteins or functional neutralization assay with various Env-pseudotyped viruses, that have been recently developed to dissect the neutralizing activity present in human sera [112-114]. These epitopes, most of them being of conformational nature, were identified thanks to the isolation of human monoclonal broadly neutralizing antibodies (HuMoNAbs) [96,115-118] (Figure 3). They are conserved regions of the $\mathrm{HIV}-1$ envelope glycoprotein such as the CD4 binding site (CD4bs) on gp120, quaternary structure dependent epitopes on the V1-V2 variable loops of gp120, glycan-dependent epitopes involving the V3 region of gp120, and the MPER of gp41. A fine 


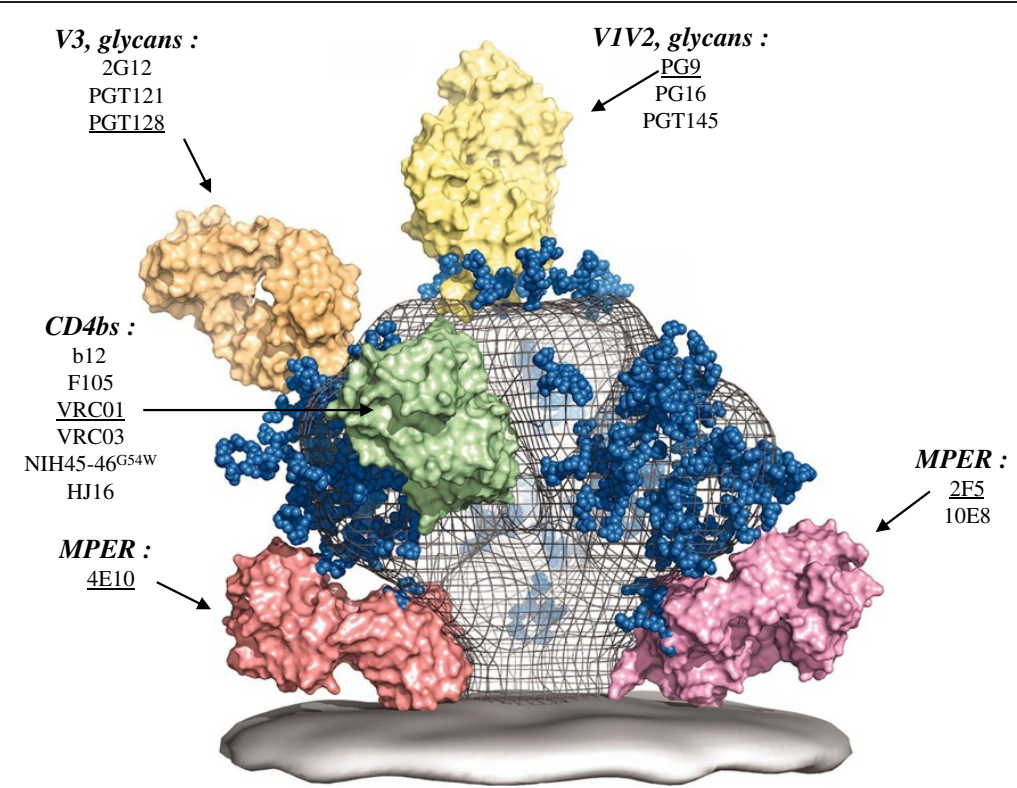

Figure 3 A model of the HIV-1 Env spike with selected HuMoNAbs Fabs bound to their conserved epitopes. Adapted with permission from AAAS - Burton et al. [118]. The names of selected HuMoNAbs are underlined. The locations of their targeted epitopes are indicated in bold and italic. The name of other HuMoNabs targeting similar epitopes is included [96,115-117,152,153].

comparison of the specificity of the neutralizing response between transmitting and non-transmitting mothers by such extensive serum mapping using Env proteins or Envpseudotyped viruses derived from HIV-1 strains indicator of protective antibodies should help to define more precisely if some antibody specificities correlate with protection in the MTCT context.

In the absence of antiretroviral prophylaxis, HIV is transmitted via breastfeeding to only $10-15 \%$ of infants, despite daily milk exposure. This suggests that breast milk may contain antiviral immune factors protecting most infants from mucosal HIV infections. HIV-1 envelopespecific antibody responses have been detected in milk. However, despite a predominance of secretory IgA in milk, the magnitude of the HIV-1 envelope-specific IgA activity is lower than that of envelope-specific IgG activity [119-122]. Similarly, the predominant SIV envelopespecific antibodies in milk from lactating rhesus monkeys are of the IgG isotype [123]. This is in accordance with what has been observed in other mucosal compartments, such as genital tract and saliva [119,120,124-128]. A few studies explored the putative role of envelope-specific antibodies present in breast milk of infected mothers to prevent infant infection. Quantitative studies of HIV or SIV envelope-specific binding antibodies did not reveal any difference between transmitting and non-transmitting mothers [129-131]. However, the neutralizing activity of these antibodies was not analyzed in these studies. Two recent studies made extensive comparisons of the neutralizing and antibody-dependent cellular cytotoxicity
(ADCC) responses in breast milk and plasma from African HIV-infected lactating women [122,132]. Although lower in magnitude, the neutralizing and ADCC activities in milk were directly correlated with those in plasma and were primarily mediated by plasma-derived IgG antibodies. Similarly, SIV-specific IgA antibodies had limited neutralization potency compared to SIVspecific IgG in SIV-infected rhesus monkeys [123]. This suggests that IgA-mediated neutralizing and ADCC responses did not play a major role in preventing MTCT transmission via breastfeeding. However, the capacity of milk IgA to block HIV-1 transcytosis across epithelial cells was not studied. Such a protective role, recently reported for preventing vaginal and rectal infections in animal models, cannot be excluded [133,134]. The preventing role of IgG responses in mothers' milk is difficult to explore due to the presence in newborns of high physiological levels of passively acquired maternal IgG. One study reported a higher magnitude of milk IgGmediated ADCC in HIV-1-infected women who did not transmit HIV to their infants postnatally than in transmitters [132]. This suggests that an efficient vaccine should be able to induce a protective humoral response that could be transferred also through breastfeeding.

\section{Studies of passive immunization in newborn macaques: sterilizing immunity}

The development of MTCT models of SIV infection in macaques has been very useful to evaluate the potential of passively transferred antibodies to prevent infection. 
A first attempt of passive immunization of newborn rhesus macaques with pooled sera from chronically SIVinfected rhesus macaques has been shown to be protective from oral SIV exposure that mimics the mucosal exposure occurring during perinatal and breast-milk HIV1 transmission (Table 2) [1]. However, the precise mechanism for the protection could not be established as no neutralizing activity of these pooled sera could be detected in vitro against the challenge virus. At about the same time, the first HuMoNAbs, F105, 2F5, 4E10, 2 G12 and b12, were generated and characterized (Figure 3). F105 and b12 are directed against the CD4 binding site of gp120 [135,136], 2G12 recognizes a conformational carbohydrate-dependent epitope on gp120 [137], and 2F5 and 4E10 are directed against the MPER of gp41
$[138,139]$. To evaluate the capacity of these HuMoNAbs to prevent HIV-1 infection, chimeric simian-human immunodeficiency viruses (SHIV) were used. Because the SIV and HIV envelope glycoproteins are too divergent to analyze their sensitivity to NAbs, SHIV were constructed based on a SIV backbone in which the SIV env gene was replaced by an HIV-1 env gene. The first SHIV constructs expressed the env gene of the T-cell line laboratory-adapted (TCLA) HIV strain IIIB which is highly neutralization-sensitive [140-143], but constructs using env genes from primary HIV-1 isolates were subsequently made, generating more pathogenic and more neutralization-resistant SHIV viruses [144-147]. Using the SHIV-macaque model, several studies have shown that passive administration of high concentrations of various

Table 2 Studies of passive immunization in newborn macaques

\begin{tabular}{|c|c|c|c|c|c|}
\hline \multicolumn{2}{|c|}{ Treatment } & \multicolumn{2}{|c|}{ Challenge } & \multirow{2}{*}{$\begin{array}{c}\text { Sterile } \\
\text { protection }\end{array}$} & \multirow[t]{2}{*}{ References } \\
\hline Antibody (Route, Concentration) & Infusion timing & Virus & Route & & \\
\hline \multirow{3}{*}{$\begin{array}{l}\text { SIV hyperimmune serum } \\
\text { (SC, } 20 \mathrm{~mL} / \mathrm{kg})\end{array}$} & - Postnatal 2 days before challenge & & & $-2 / 2$ & \\
\hline & $\begin{array}{l}\text { - Postnatal } 2 \text { days before challenge } \\
\text { and } 5 \text { and } 12 \text { days after challenge }\end{array}$ & $\begin{array}{l}\text { SIVmac } 251 \\
\left(10^{5} \text { TCID50) }\right.\end{array}$ & Oral & $-4 / 4$ & {$[1]$} \\
\hline & - Postanatal 3 weeks after challenge & & & $-0 / 3$ & \\
\hline $\begin{array}{l}\text { - HIV immune globin (HIVIG) } \\
\text { (IV, } 400 \text { mg/kg) }\end{array}$ & \multirow{5}{*}{$\begin{array}{l}\text { Postnatal } 24 \text { hours } \\
\text { before challenge }\end{array}$} & \multirow{5}{*}{$\begin{array}{l}\text { SHIV89.6PD } \\
(40 \text { TCID50) }\end{array}$} & \multirow{5}{*}{ IV } & $-0 / 3$ & \multirow{5}{*}[3]{} \\
\hline - 2F5 (IV, 15 mg/kg) & & & & $-0 / 3$ & \\
\hline - 2G12 (IV, 15 mg/kg) & & & & $-0 / 3$ & \\
\hline $\begin{array}{c}-2 \mathrm{~F} 5 \text { / 2G12 } \\
(\mathrm{IV}, 15 \mathrm{mg} / \mathrm{kg} \text { of each) }\end{array}$ & & & & $-0 / 3$ & \\
\hline $\begin{array}{c}-\mathrm{HIVIG} / 2 \mathrm{~F} 5 / 2 \mathrm{G} 12 \\
(\mathrm{IV}, 400 \mathrm{mg} / \mathrm{kg} \text { of HIVIG, } 15 \mathrm{mg} / \mathrm{kg} \\
\text { of each HuMoNAb) }\end{array}$ & & & & $-3 / 6$ & \\
\hline $\begin{array}{c}\text { F105/2G12/2F5 } \\
\text { (IV, } 10 \mathrm{mg} / \mathrm{kg} \text { of each) }\end{array}$ & $\begin{array}{l}\text { Pre- and postnatal 1-4 hours before } \\
\text { and } 8 \text { days after challenge }\end{array}$ & $\begin{array}{l}\text { SHIVIIIB-vpu } \\
(10 \text { AID50) }\end{array}$ & Oral & $4 / 4$ & {$[4]$} \\
\hline $\begin{array}{l}\text { 2G12/b12/2 F5 } \\
\text { (IV, } 10 \mathrm{mg} / \mathrm{kg} \text { of each) }\end{array}$ & $\begin{array}{c}\text { Postnatal } 1 \text { hour before and } 8 \text { days } \\
\text { after challenge }\end{array}$ & $\begin{array}{c}\text { - SHIVIIIB-vpu }{ }^{+} \\
\text {(10 AID50) } \\
\text { - SHIV-89.6P } \\
\text { (15 AID50) }\end{array}$ & Oral & $-1 / 4$ & {$[148]$} \\
\hline \multirow{2}{*}{$\begin{array}{c}\text { F105/2G12/2F5 } \\
\text { (IV, } 10 \mathrm{mg} / \mathrm{kg} \text { of each) }\end{array}$} & $\begin{array}{l}\text { - Postnatal 3-4 hours before } \\
\text { challenge and } 8 \text { days after challenge }\end{array}$ & \multirow{2}{*}{$\begin{array}{l}\text { SHIVIIIB-vpu } \\
(10 \text { AID50) }\end{array}$} & \multirow{2}{*}{ Oral } & $-2 / 2$ & \multirow{2}{*}[149]{} \\
\hline & $\begin{array}{c}\text { - Postnatal } 1 \text { hour and } 8 \text { days after } \\
\text { challenge }\end{array}$ & & & $-2 / 2$ & \\
\hline $\begin{array}{c}\text { 2G12/b12/2F5/4E10 } \\
(\mathrm{IV}, 30 \mathrm{mg} / \mathrm{kg} \text { of each except 4E10 } \\
\text { at } 11.5 \mathrm{mg} / \mathrm{kg})\end{array}$ & $\begin{array}{c}\text { Postnatal } 1 \text { hour and } 8 \text { days after } \\
\text { challenge }\end{array}$ & $\begin{array}{l}\text { SHIV-89.6P } \\
(15 \text { AID50) }\end{array}$ & Oral & $2 / 4$ & {$[6]$} \\
\hline $\begin{array}{c}\text { 2G12/2F5/4E10 } \\
\text { (IM, } 40 \mathrm{mg} / \mathrm{kg} \text { of each) }\end{array}$ & $\begin{array}{c}\text { Postnatal } 1 \text { hour and } 8 \text { days after } \\
\text { challenge }\end{array}$ & $\begin{array}{l}\text { SHIV-89.6P } \\
(15 \text { AID50) }\end{array}$ & Oral & $4 / 4$ & {$[150]$} \\
\hline \multirow{2}{*}{$\begin{array}{l}-2 \mathrm{G} 12 / \mathrm{b} 12 / 2 \text { F5/4E10 } \\
\text { (IV, } 30 \mathrm{mg} / \mathrm{kg} \text { of each) }\end{array}$} & $\begin{array}{c}\text { - Postnatal } 1 \text { hour and } 8 \text { days after } \\
\text { challenge }\end{array}$ & & & $-3 / 4$ & \multirow{3}{*}[151]{} \\
\hline & $\begin{array}{c}\text { - Post natal } 12 \text { hours and } 8 \text { days after } \\
\text { challenge }\end{array}$ & $\begin{array}{l}\text { SHIV-89.6P } \\
(15 \text { AID50) }\end{array}$ & Oral & $-1 / 4$ & \\
\hline $\begin{array}{c}-2 \mathrm{G} 12 / 2 \mathrm{~F} 5 / 4 \mathrm{E} 10 \\
\text { (IM, } 40 \mathrm{mg} / \mathrm{kg} \text { of each) }\end{array}$ & $\begin{array}{c}\text { - Postnatal } 24 \text { hours and } 9 \text { days post } \\
\text { challenge }\end{array}$ & & & $-0 / 4$ & \\
\hline
\end{tabular}


combinations of the first-generation HuMoNAbs protected neonatal rhesus macaques against high-dose intravenous or oral challenge with SHIVs (Table 2) [3,4,6,148-151]. These results provided the proof-of-concept that antibodies can prevent infection. However the current SHIV models, which include only a few HIV Envs, provide data that are limited to protection against a restricted number of isolates and therefore has limitations when considering the high diversity of HIV-1 isolates. In addition, these studies highlighted the importance of the timing of administration, since HuMoNAbs must be present at the time of viral challenge or only a few hours later to prevent the establishment of infection (sterilizing immunity) of the newborn macaques (Table 2) (Figure 4A). There was no protection when antibodies were administered more than 12 hours post-virus inoculation (Figure 4B). Recently, the association of several technological advances allowed the identification of new second-generation HuMoNAbs (particularly the PG, PGT and VRC series) that are tenfold to 100 -fold more potent in vitro than the first-generation HuMoNAbs used in passive immunization studies [96,115-117,152,153] (Figure 3). One of these antibodies, PGT121, was able to mediate sterilizing immunity against high-dose mucosal viral challenge in adult rhesus macaques at serum concentrations that were significantly lower than those observed in previous studies [154]. In addition, Klein et al. re-examined the possibility to use antibody transfer as a therapeutic modality [155]. Using a humanized mice model and combinations of these new NAbs that target complementary

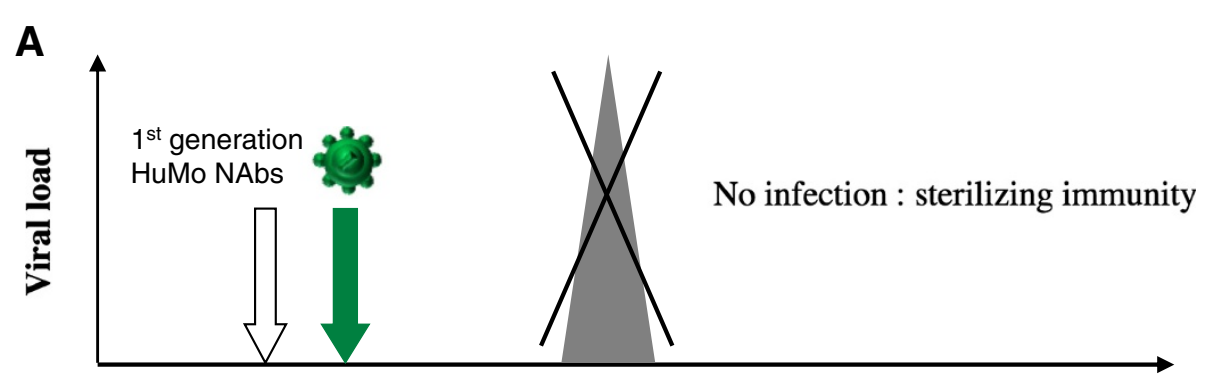

Time
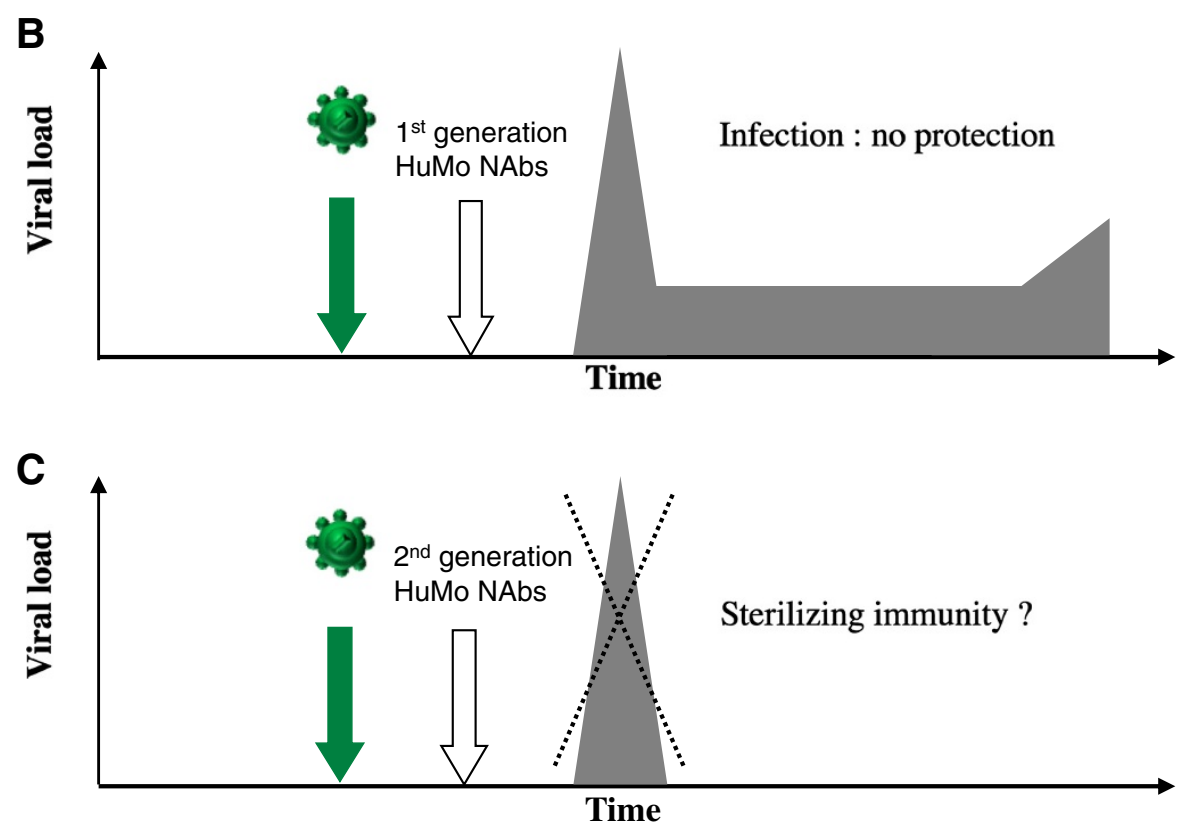

Figure 4 Studies of passive immunization in newborn macaques. A. Passive administration of high concentrations of various combinations of the first-generation HuMoNAbs (b12, 2G12, 2F5, 4E10, F105) (white arrow) before or simultaneously with intravenous or oral challenge with SHIVs (green arrow) protected neonatal rhesus macaques against infection: there was no infection $[4,149,150]$. B. There was no protection when the first-generation HuMoNAbs (white arrow) were administered more than 12 hours post-virus inoculation (green arrow) [151]. C. New secondgeneration HuMoNAbs (PG-, PGT-, VRC-series) that are 10- to 100-fold more potent in vitro than the first-generation HuMoNAbs have been identified $[96,115-117,152,153]$. It would be interesting to re-evaluate the potential protective potency of NAbs in newborn macaques when administered either before or after (white arrow) viral exposure (green arrow). 
sites on the HIV-1 spike protein, they showed that these antibodies could effectively control HIV-1 infection and suppress viral load to levels below detection. Given these new data, it would be interesting to evaluate the protective potency of these new NAbs in newborn macaques for both pre-exposure and post-exposure prophylaxies (Figure 4C). Indeed, a recent study of passive administration of neutralizing IgG (including the HuMoNAb b12) at levels insufficient to block infection to newborn macaques before oral challenge with a SHIV virus has shown that immunized macaques rapidly developed NAbs and had a significantly reduced plasma viremia [156]. This supports the use of NAbs to augment $B$ cell responses and viral control in perinatal settings, although further studies are needed to understand the mechanisms underlying their beneficial effects.

\section{Prevention of mother to child transmission : immunoprophylaxis}

MTCT of HIV-1 infection remains a significant problem in developing countries. Antiretroviral (ARV) prophylaxis can reduce the number of infections, but it does not eliminate the transmission risk. ARV efficacy is highly dependent on strict adherence to daily administration that is difficult to achieve for many women/babies. Even with optimal prophylaxis, infections occur at a rate of 1 to $5 \%$ at 6 months of age in infants of HIV-1 infected mothers who breastfeed [157]. Additional interventions that ideally do not rely on daily adherence to prevent transmission during prolonged breastfeeding need to be identified [158]. The use of an anti-HIV-1 passive immunization approach in addition to ARV prophylaxis could provide additional protection and deserves to be explored.

Passive immunization experiments of rhesus macaques have proven that NAbs can protect from MTCT. In humans, there are only 2 phase III studies of passive immunization to prevent MTCT that have been conducted. Both used polyclonal hyperimmune globulin preparations from HIV-1-infected donors. The first study was conducted in 1993-1997 in the United States in a non-breastfeeding population of HIV-1 infected pregnant women receiving zidovudine prophylaxis [159]. The second was conducted in 2004-2006 in Uganda in breastfeeding pregnant mothers receiving single-dose nevirapine [160]. Although the infusion of HIV hyperimmune preparations was proven to be safe, no additional benefit of these polyclonal preparations compared to antiretroviral treatment alone was shown in these two studies. However, it may be possible that polyclonal preparations did not contain enough NAbs specificities able to provide sterilizing immunity. The use of HuMoNAbs may be more appropriate to reach this goal and it was proposed to use them in human clinical trials $[161,162]$.
However, several of the first-generation antibodies (b12, 2F5 and 2G12) were found ineffective or only partly effective against non- $B$ viruses, particularly toward a panel of clade $C$ Env-pseudotyped viruses derived from primary isolates of South African infected children and consequently did not seem to be relevant to prevent MTCT in populations where non-B viruses predominate [163]. In contrast, the second-generation of broadly HuMoNAbs directed against quaternary epitopes (PG9, PG16), the CD4bs epitopes (VRC01, NIH45-46 ${ }^{\mathrm{G} 54 \mathrm{~W}}$ ) and V3 glycandependent epitopes (PGT121, PGT128) were recently found to be able to neutralize most of HIV-1 non-B variants transmitted through breastfeeding [89,164-166]. Similarly, by comparing functional properties of CRF01$\mathrm{AE}$ variants transmitted perinatally to infants with those of their chronically infected mothers, we recently found that all the transmitted variants were highly sensitive to both PG9 and PG16, significantly more sensitive than the maternal variants [95]. Together, these data would suggest that this new generation of HuMoNAbs could be efficient in passive immunization strategies. HIV prevention trials in African breastfed infants using the antibody HuMoNAb VRC01 are currently considered [167].

\section{Conclusions}

There are strong evidences for a selective advantage of the HIV-1 variants that are transmitted from the mother to the infant in the presence of maternal HIV-1-specific antibodies. An association between presence or titers of NAbs toward different HIV-1 strains and a lower rate of mother-to-child transmission has been found in several studies, suggesting that some NAbs could contribute to protection toward neonatal infection. Together, these data suggest that some neutralizing specificities might be protective and, in case of transmission, that the transmitted variants escape these specificities. Dissecting the antibody specificities that mediate protection toward MTCT of HIV-1 could provide important clues for identification of correlates of protection that would be useful for vaccine development. Experiments of passive immunization in newborn macaques have shown that first-generation HuMoNAbs can fully protect against SHIV infection, providing additional proof that NAbs can inhibit MTCT. The recent identification of highly potent second-generation HuMoNAbs provides a new opportunity to evaluate the efficacy of passive immunization to prevent mother-to-child transmission of HIV-1.

\section{Abbreviations}

NAbs: Neutralizing antibodies; MTCT: Mother-to-child transmission; HuMoNAbs: Human monoclonal neutralizing antibodies; HIV: Human immunodeficiency virus; PNGS: Potential N-linked glycosylation site; MPER: Membrane-proximal external region; CD4bs: CD4 binding site; ADCC: Antibody-dependent cellular cytotoxicity; SHIV: Simian-human immunodeficiency virus; TCLA virus: T-cell line laboratory-adapted virus; ARV: Antiretroviral. 


\section{Competing interests}

The authors declare no competing interests.

\section{Authors' contributions}

$\mathrm{MB}$ and $\mathrm{FB}$ wrote the manuscript. All authors read and approve the final manuscript.

\section{Acknowledgments}

Work on MTCT and NAbs in the laboratory was supported by the Agence Nationale de Recherches sur le SIDA et les hépatites (ANRS, Paris, France) and by Sidaction (Paris, France).

\section{Author details}

'Université François-Rabelais, UFR Médecine, Inserm U966 10 bld Tonnellé, cedex, 37032 Tours, France. ${ }^{2}$ Centre National de Référence VIH, Laboratoire de Bactériologie-Virologie, CHU Bretonneau, Tours, France.

Received: 7 August 2013 Accepted: 10 September 2013 Published: 7 October 2013

\section{References}

1. Van Rompay KK, Berardi CJ, Dillard-Telm S, Tarara RP, Canfield DR, Valverde CR, Montefiori DC, Cole KS, Montelaro RC, Miller CJ, Marthas ML: Passive immunization of newborn rhesus macaques prevents oral simian immunodeficiency virus infection. J Infect Dis 1998, 177:1247-1259.

2. Foresman L, Jia F, Li Z, Wang C, Stephens EB, Sahni M, Narayan O, Joag SV: Neutralizing antibodies administered before, but not after, virulent SHIV prevent infection in macaques. AIDS Res Hum Retroviruses 1998, 14:1035-1043.

3. Mascola JR, Lewis MG, Stiegler G, Harris D, VanCott TC, Hayes D, Louder MK, Brown CR, Sapan CV, Frankel SS, et al: Protection of macaques against pathogenic simian/human immunodeficiency virus 89.6PD by passive transfer of neutralizing antibodies. J Virol 1999, 73:4009-4018.

4. Baba TW, Liska V, Hofmann-Lehmann R, Vlasak J, Xu W, Ayehunie S, Cavacini $L A$, Posner MR, Katinger $H$, Stiegler $G$, et al: Human neutralizing monoclonal antibodies of the lgG1 subtype protect against mucosal simian-human immunodeficiency virus infection. Nat Med 2000, 6:200-206.

5. Mascola JR, Stiegler G, VanCott TC, Katinger H, Carpenter CB, Hanson CE, Beary $H$, Hayes D, Frankel SS, Birx DL, Lewis MG: Protection of macaques against vaginal transmission of a pathogenic HIV-1/SIV chimeric virus by passive infusion of neutralizing antibodies. Nat Med 2000, 6:207-210.

6. Ferrantelli F, Hofmann-Lehmann R, Rasmussen RA, Wang T, Xu W, Li PL, Montefiori DC, Cavacini LA, Katinger H, Stiegler G, et al: Post-exposure prophylaxis with human monoclonal antibodies prevented SHIV89.6P infection or disease in neonatal macaques. AIDS 2003, 17:301-309.

7. Hessell AJ, Hangartner L, Hunter M, Havenith CE, Beurskens FJ, Bakker JM, Lanigan CM, Landucci G, Forthal DN, Parren PW, et al: Fc receptor but not complement binding is important in antibody protection against HIV. Nature 2007, 449:101-104.

8. Hessell AJ, Poignard P, Hunter M, Hangartner L, Tehrani DM, Bleeker WK, Parren PW, Marx PA, Burton DR: Effective, low-titer antibody protection against low-dose repeated mucosal SHIV challenge in macaques. Nat Med 2009, 15:951-954.

9. Hessell AJ, Rakasz EG, Poignard P, Hangartner L, Landucci G, Forthal DN, Koff WC, Watkins DI, Burton DR: Broadly neutralizing human anti-HIV antibody $2 \mathrm{G} 12$ is effective in protection against mucosal SHIV challenge even at low serum neutralizing titers. PLOS Pathog 2009, 5:e1000433.

10. Burton DR, Hessell AJ, Keele BF, Klasse PJ, Ketas TA, Moldt B, Dunlop DC, Poignard P, Doyle LA, Cavacini L, et al: Limited or no protection by weakly or nonneutralizing antibodies against vaginal SHIV challenge of macaques compared with a strongly neutralizing antibody. Proc Natl Acad Sci USA 2011, 108:11181-11186.

11. Berman PW: Development of bivalent rgp120 vaccines to prevent HIV type 1 infection. AIDS Res Hum Retroviruses 1998, 14(Suppl 3):S277-S289.

12. Francis DP, Gregory T, McElrath MJ, Belshe RB, Gorse GJ, Migasena S, Kitayaporn D, Pitisuttitham P, Matthews T, Schwartz DH, Berman PW: Advancing AIDSVAX to phase 3. Safety, immunogenicity, and plans for phase 3. AIDS Res Hum Retroviruses 1998, 14(Suppl 3):S325-S331.

13. Berman PW, Huang W, Riddle L, Gray AM, Wrin T, Vennari J, Johnson A, Klaussen M, Prashad H, Kohne C, et al: Development of bivalent (B/E) vaccines able to neutralize CCR5-dependent viruses from the United States and Thailand. Virology 1999, 265:1-9.

14. Gilbert PB, Peterson ML, Follmann D, Hudgens MG, Francis DP, Gurwith M, Heyward WL, Jobes DV, Popovic V, Self SG, et al: Correlation between immunologic responses to a recombinant glycoprotein 120 vaccine and incidence of HIV-1 infection in a phase 3 HIV-1 preventive vaccine trial. J Infect Dis 2005, 191:666-677.

15. Flynn NM, Forthal DN, Harro CD, Judson FN, Mayer KH, Para MF: Placebocontrolled phase 3 trial of a recombinant glycoprotein 120 vaccine to prevent HIV-1 infection. J Infect Dis 2005, 191:654-665.

16. Pitisuttithum $P$, Gilbert $P$, Gurwith $M$, Heyward W, Martin M, van Griensven F, Hu D, Tappero JW, Choopanya K: Randomized, double-blind, placebocontrolled efficacy trial of a bivalent recombinant glycoprotein $120 \mathrm{HIV}$ 1 vaccine among injection drug users in Bangkok, Thailand. $J$ Infect Dis 2006, 194:1661-1671.

17. Gilbert $P$, Wang M, Wrin T, Petropoulos C, Gurwith M, Sinangil F, D'Souza $P$, Rodriguez-Chavez IR, DeCamp A, Giganti M, et al: Magnitude and breadth of a nonprotective neutralizing antibody response in an efficacy trial of a candidate HIV-1 gp120 vaccine. J Infect Dis 2010, 202:595-605.

18. Rerks-Ngarm S, Pitisuttithum P, Nitayaphan S, Kaewkungwal J, Chiu J, Paris R, Premsri N, Namwat C, de Souza M, Adams E, et al: Vaccination with ALVAC and AIDSVAX to prevent HIV-1 infection in Thailand. N Engl J Med 2009, 361:2209-2220.

19. Liao HX, Lynch R, Zhou T, Gao F, Alam SM, Boyd SD, Fire AZ, Roskin KM, Schramm CA, Zhang Z, et al: Co-evolution of a broadly neutralizing HIV-1 antibody and founder virus. Nature 2013, 496:469-476.

20. Jardine J, Julien JP, Menis S, Ota T, Kalyuzhniy O, McGuire A, Sok D, Huang PS, Macpherson S, Jones M, et al: Rational HIV immunogen design to target specific germline B cell receptors. Science 2013, 340:711-716.

21. McGuire AT, Hoot S, Dreyer AM, Lippy A, Stuart A, Cohen KW, Jardine J, Menis S, Scheid JF, West AP, et al: Engineering HIV envelope protein to activate germline $B$ cell receptors of broadly neutralizing anti-CD4 binding site antibodies. J Exp Med 2013, 210:655-663.

22. Klein F, Diskin R, Scheid JF, Gaebler C, Mouquet H, Georgiev IS, Pancera M, Zhou $T$, Incesu RB, Fu BZ, et al: Somatic mutations of the immunoglobulin framework are generally required for broad and potent HIV-1 neutralization. Cell 2013, 153:126-138.

23. Scheid JF, Mouquet H, Ueberheide B, Diskin R, Klein F, Oliveira TY, Pietzsch J, Fenyo D, Abadir A, Velinzon K, et al: Sequence and structural convergence of broad and potent HIV antibodies that mimic CD4 binding. Science 2011, 333:1633-1637.

24. Corti D, Lanzavecchia A: Broadly neutralizing antiviral antibodies. Annu Rev Immunol 2013, 31:705-742.

25. Mascola JR, Haynes BF: HIV-1 neutralizing antibodies: understanding nature's pathways. Immunol Rev 2013, 254:225-244.

26. European Collaborative Study: Children born to women with HIV-1 infection: natural history and risk of transmission. Lancet 1991, 337:253-260.

27. Lepage $P$, Van de Perre $P$, Msellati $P$, Hitimana DG, Simonon A, Van Goethem C, Mukamabano B, Karita E, Stevens AM, Mathieu G, et al: Motherto-child transmission of human immunodeficiency virus type 1 (HIV-1) and its determinants: a cohort study in Kigali, Rwanda. Am J Epidemiol 1993, 137:589-599.

28. Lallemant M, Le Coeur S, Samba L, Cheynier D, M'Pele P, Nzingoula S, Essex M: Mother-to-child transmission of HIV-1 in Congo, central Africa. Congolese research group on mother-to-Child transmission of HIV. Aids 1994, 8:1451-1456.

29. De Cock KM, Fowler MG, Mercier E, de Vincenzi I, Saba J, Hoff E, Alnwick DJ, Rogers M, Shaffer N: Prevention of mother-to-child HIV transmission in resource-poor countries: translating research into policy and practice. Jama 2000, 283:1175-1182.

30. Matheron S, Courpotin C, Simon F, Di Maria H, Balloul H, Bartzack S, Dormont D, Brun Vezinet F, Saimot AG, Coulaud JP: Vertical transmission of HIV-2. Lancet 1990, 335:1103-1104

31. Andreasson PA, Dias F, Naucler A, Andersson S, Biberfeld G: A prospective study of vertical transmission of HIV-2 in Bissau, Guinea-Bissau. Aids 1993, 7:989-993

32. Adjorlolo-Johnson G, De Cock KM, Ekpini E, Vetter KM, Sibailly T, Brattegaard K, Yavo D, Doorly R, Whitaker JP, Kestens L, et al: Prospective comparison of mother-to-child transmission of HIV-1 and HIV-2 in Abidjan, Ivory Coast. Jama 1994, 272:462-466. 
33. O'Donovan D, Ariyoshi K, Milligan P, Ota M, Yamuah L, Sarge-Njie R, Whittle H: Maternal plasma viral RNA levels determine marked differences in motherto-child transmission rates of HIV-1 and HIV-2 in the Gambia. MRC/Gambia government/university college London medical school working group on mother-child transmission of HIV. Aids 2000, 14:441-448.

34. Burgard M, Jasseron C, Matheron S, Damond F, Hamrene K, Blanche S, Faye A, Rouzioux C, Warszawski J, Mandelbro L: Mother-to-child transmission of HIV-2 infection from 1986 to 2007 in the ANRS French perinatal cohort EPF-CO1. Clin Infect Dis 2010, 51:833-843.

35. European Collaborative Study: Risk factors for mother-to-child transmission of HIV-1. Lancet 1992, 339:1007-1012.

36. Simon F, Matheron S, Tamalet C, Loussert-Ajaka I, Bartczak S, Pepin JM, Dhiver C, Gamba E, Elbim C, Gastaut JA, et al: Cellular and plasma viral load in patients infected with HIV-2. Aids 1993, 7:1411-1417.

37. Popper SJ, Sarr AD, Travers KU, Gueye-Ndiaye A, Mboup S, Essex ME, Kanki $P J$ : Lower human immunodeficiency virus (HIV) type 2 viral load reflects the difference in pathogenicity of HIV-1 and HIV-2. J Infect Dis 1999, 180:1116-1121.

38. Ariyoshi K, Jaffar S, Alabi AS, Berry N, Schim van der Loeff M, Sabally S, N'Gom PT, Corrah T, Tedder R, Whittle H: Plasma RNA viral load predicts the rate of CD4 T cell decline and death in HIV-2-infected patients in west Africa. Aids 2000, 14:339-344.

39. Matheron S, Pueyo S, Damond F, Simon F, Lepretre A, Campa P, Salamon R, Chene G, Brun-Vezinet F: Factors associated with clinical progression in HIV-2 infected-patients: the French ANRS cohort. Aids 2003, 17:2593-2601.

40. Drylewicz J, Matheron S, Lazaro E, Damond F, Bonnet F, Simon F, Dabis F, Brun-Vezinet F, Chene $G$, Thiebaut R: Comparison of viro-immunological marker changes between HIV-1 and HIV-2-infected patients in France. Aids 2008, 22:457-468

41. Malek A, Sager R, Kuhn P, Nicolaides KH, Schneider H: Evolution of maternofetal transport of immunoglobulins during human pregnancy. Am J Reprod Immunol 1996, 36:248-255.

42. Simister NE: Placental transport of immunoglobulin G. Vaccine 2003, 21:3365-3369.

43. Gusdon JP Jr: Fetal and maternal immunoglobulin levels during pregnancy. Am J Obstet Gynecol 1969, 103:895-900.

44. Morell A, Skvaril F, Steinberg AG, Van Loghem E, Terry WD: Correlations between the concentrations of the four sub-classes of IgG and $\mathrm{Gm}$ allotypes in normal human sera. J Immunol 1972, 108:195-206.

45. Garty BZ, Ludomirsky A, Danon YL, Peter JB, Douglas SD: Placental transfer of immunoglobulin G subclasses. Clin Diagn Lab Immunol 1994, 1:667-669.

46. Morell A, Skvaril F, van Loghem E, Kleemola M: Human IgG subclasses in maternal and fetal serum. Vox Sang 1971, 21:481-492.

47. Schur PH, Alpert E, Alper C: Gamma G subgroups in human fetal, cord, and maternal sera. Clin Immunol Immunopathol 1973, 2:62-66.

48. Malek A, Sager R, Schneider H: Maternal-fetal transport of immunoglobulin $\mathrm{G}$ and its subclasses during the third trimester of human pregnancy. Am J Reprod Immunol 1994, 32:8-14

49. Longsworth LG, Curtis RM, Pembroke RH: The electrophoretic analysis of maternal and fetal plasmas and sera. J Clin Invest 1945, 24:46-53.

50. Kohler PF, Farr RS: Elevation of cord over maternal lgG immunoglobulin: evidence for an active placental IgG transport. Nature 1966, 210:1070-1071.

51. Omenda MM, Milligan C, Odem-Davis K, Nduati R, Richardson BA, Lynch J, John-Stewart G, Overbaugh J: Evidence for efficient vertical transfer of maternal HIV-1 envelope-specific neutralizing antibodies but no association of such antibodies with reduced infant infection. J Acquir Immune Defic Syndr 2013. in press.

52. Simmonds $P$, Zhang LQ, McOmish F, Balfe P, Ludlam CA, Brown AJ: Discontinuous sequence change of human immunodeficiency virus (HIV) type 1 env sequences in plasma viral and lymphocyte-associated proviral populations in vivo: implications for models of HIV pathogenesis. J Virol 1991, 65:6266-6276.

53. Burger H, Weiser B, Flaherty K, Gulla J, Nguyen PN, Gibbs RA: Evolution of human immunodeficiency virus type 1 nucleotide sequence diversity among close contacts. Proc Natl Acad Sci USA 1991, 88:11236-11240.

54. Zhang LQ, MacKenzie P, Cleland A, Holmes EC, Brown AJ, Simmonds P: Selection for specific sequences in the external envelope protein of human immunodeficiency virus type 1 upon primary infection. J Virol 1993, 67:3345-3356.

55. Derdeyn CA, Decker JM, Bibollet-Ruche F, Mokili JL, Muldoon M, Denham SA, Heil ML, Kasolo F, Musonda R, Hahn BH, et al: Envelope-constrained neutralization-sensitive HIV-1 after heterosexual transmission. Science 2004, 303:2019-2022.

56. Gottlieb GS, Heath L, Nickle DC, Wong KG, Leach SE, Jacobs B, Gezahegne S, van't Wout AB, Jacobson LP, Margolick JB, Mullins Jl: HIV-1 variation before seroconversion in men who have sex with men: analysis of acute/early HIV infection in the multicenter AIDS cohort study. J Infect Dis 2008, 197:1011-1015.

57. Learn GH, Muthui D, Brodie SJ, Zhu T, Diem K, Mullins Jl, Corey L: Virus population homogenization following acute human immunodeficiency virus type 1 infection. J Virol 2002, 76:11953-11959.

58. Long EM, Martin HL Jr, Kreiss JK, Rainwater SM, Lavreys L, Jackson DJ, Rakwar J, Mandaliya K, Overbaugh J: Gender differences in HIV-1 diversity at time of infection. Nat Med 2000, 6:71-75.

59. Poss M, Martin HL, Kreiss JK, Granville L, Chohan B, Nyange P, Mandaliya K, Overbaugh J: Diversity in virus populations from genital secretions and peripheral blood from women recently infected with human immunodeficiency virus type 1. J Virol 1995, 69:8118-8122.

60. Wolfs TF, Zwart G, Bakker M, Goudsmit J: HIV-1 genomic RNA diversification following sexual and parenteral virus transmission. Virology 1992, 189:103-110

61. Wolinsky SM, Wike CM, Korber BT, Hutto C, Parks WP, Rosenblum LL, Kunstman KJ, Furtado MR, Munoz JL: Selective transmission of human immunodeficiency virus type-1 variants from mothers to infants. Science 1992, 255:1134-1137.

62. Zhu T, Mo H, Wang N, Nam DS, Cao Y, Koup RA, Ho DD: Genotypic and phenotypic characterization of HIV-1 patients with primary infection. Science 1993, 261:1179-1181.

63. Keele BF, Giorgi EE, Salazar-Gonzalez JF, Decker JM, Pham KT, Salazar MG, Sun C, Grayson T, Wang S, Li H, et al: Identification and characterization of transmitted and early founder virus envelopes in primary HIV-1 infection. Proc Natl Acad Sci USA 2008, 105:7552-7557.

64. Li H, Bar KJ, Wang S, Decker JM, Chen Y, Sun C, Salazar-Gonzalez JF, Salazar MG, Learn GH, Morgan CJ, et al: High multiplicity infection by HIV-1 in Men Who have Sex with Men. PLoS Pathog 2010, 6:e1000890.

65. Bar KJ, Li H, Chamberland A, Tremblay C, Routy JP, Grayson T, Sun C, Wang $\mathrm{S}$, Learn $\mathrm{GH}$, Morgan $\mathrm{CJ}$, et al: Wide variation in the multiplicity of HIV-1 infection among injection drug users. J Virol 2010, 84:6241-6247.

66. Abrahams MR, Anderson JA, Giorgi EE, Seoighe C, Mlisana K, Ping LH, Athreya GS, Treurnicht FK, Keele BF, Wood N, et al: Quantitating the multiplicity of infection with human immunodeficiency virus type 1 subtype $C$ reveals a non-poisson distribution of transmitted variants. J Virol 2009, 83:3556-3567.

67. Haaland RE, Hawkins PA, Salazar-Gonzalez J, Johnson A, Tichacek A, Karita E, Manigart O, Mulenga J, Keele BF, Shaw GM, et al: Inflammatory genital infections mitigate a severe genetic bottleneck in heterosexual transmission of subtype A and C HIV-1. PLOS Pathog 2009, 5:e1000274.

68. Wike CM, Korber BT, Daniels MR, Hutto C, Munoz J, Furtado M, Parks W, Saah A, Bulterys M, Kurawige JB, et al: HIV-1 sequence variation between isolates from mother-infant transmission pairs. AIDS Res Hum Retroviruses 1992, 8:1297-1300

69. Scarlatti G, Leitner T, Halapi E, Wahlberg J, Marchisio P, Clerici-Schoeller MA, Wigzell $H$, Fenyo EM, Albert J, Uhlen M, et al: Comparison of variable region 3 sequences of human immunodeficiency virus type 1 from infected children with the RNA and DNA sequences of the virus populations of their mothers. Proc Natl Acad Sci USA 1993, 90:1721-1725.

70. Mulder-Kampinga GA, Kuiken C, Dekker J, Scherpbier HJ, Boer K, Goudsmit J: Genomic human immunodeficiency virus type 1 RNA variation in mother and child following intra-uterine virus transmission. J Gen Virol 1993, 74:1747-1756.

71. van't Wout AB, Kootstra NA, Mulder-Kampinga GA, Albrecht-van Lent N, Scherpbier HJ, Veenstra J, Boer K, Coutinho RA, Miedema F, Schuitemaker H: Macrophage-tropic variants initiate human immunodeficiency virus type 1 infection after sexual, parenteral, and vertical transmission. J Clin Invest 1994, 94:2060-2067.

72. Lamers SL, Sleasman JW, She JX, Barrie KA, Pomeroy SM, Barrett DJ, Goodenow MM: Persistence of multiple maternal genotypes of human immunodeficiency virus type I in infants infected by vertical transmission. J Clin Invest 1994, 93:380-390.

73. Ahmad N, Baroudy BM, Baker RC, Chappey C: Genetic analysis of human immunodeficiency virus type 1 envelope $\mathrm{V} 3$ region isolates from mothers and infants after perinatal transmission. J Virol 1995, 69:1001-1012. 
74. Briant L, Wade CM, Puel J, Brown AJ, Guyader M: Analysis of envelope sequence variants suggests multiple mechanisms of mother-to-child transmission of human immunodeficiency virus type 1. J Virol 1995, 69:3778-3788.

75. Pasquier C, Cayrou C, Blancher A, Tourne-Petheil C, Berrebi A, Tricoire J, Puel $\mathrm{J}$, Izopet J: Molecular evidence for mother-to-child transmission of multiple variants by analysis of RNA and DNA sequences of human immunodeficiency virus type 1. J Virol 1998, 72:8493-8501.

76. Sutthent R, Foongladda S, Chearskul S, Wanprapa N, Likanonskul S, Kositanont U, Riengrojpitak S, Sahaphong S, Wasi C: V3 Sequence diversity of HIV-1 subtype $\mathrm{E}$ in infected mothers and their infants. J Acquir Immune Defic Syndr Hum Retrovirol 1998, 18:323-331.

77. Dickover RE, Garratty EM, Plaeger S, Bryson YJ: Perinatal transmission of major, minor, and multiple maternal human immunodeficiency virus type 1 variants in utero and intrapartum. J Virol 2001, 75:2194-2203.

78. Zhang H, Orti G, Du Q, He J, Kankasa C, Bhat G, Wood C: Phylogenetic and phenotypic analysis of HIV type 1 env gp120 in cases of subtype $C$ mother-to-child transmission. AIDS Res Hum Retroviruses 2002, 18:1415-1423

79. Verhofstede C, Demecheleer E, De Cabooter N, Gaillard P, Mwanyumba F, Claeys P, Chohan V, Mandaliya K, Temmerman M, Plum J: Diversity of the human immunodeficiency virus type 1 (HIV-1) env sequence after vertical transmission in mother-child pairs infected with HIV-1 subtype A. J Virol 2003, 77:3050-3057.

80. Dickover R, Garratty E, Yusim K, Miller C, Korber B, Bryson Y: Role of maternal autologous neutralizing antibody in selective perinatal transmission of human immunodeficiency virus type 1 escape variants. $J$ Virol 2006, 80:6525-6533.

81. Wu X, Parast AB, Richardson BA, Nduati R, John-Stewart G, Mbori-Ngacha D, Rainwater SM, Overbaugh J: Neutralization escape variants of human immunodeficiency virus type 1 are transmitted from mother to infant. $J$ Virol 2006, 80:835-844.

82. Rainwater SM, Wu X, Nduati R, Nedellec R, Mosier D, John-Stewart G, MboriNgacha D, Overbaugh J: Cloning and characterization of functional subtype A HIV-1 envelope variants transmitted through breastfeeding. Curr HIV Res 2007, 5:189-197.

83. Hoffmann FG, He X, West JT, Lemey P, Kankasa C, Wood C: Genetic variation in mother-child acute seroconverter pairs from Zambia. AIDS 2008, 22:817-824.

84. Kwiek JJ, Russell ES, Dang KK, Burch CL, Mwapasa V, Meshnick SR, Swanstrom R: The molecular epidemiology of HIV-1 envelope diversity during HIV-1 subtype $C$ vertical transmission in Malawian mother-infant pairs. AIDS 2008, 22:863-871

85. Samleerat T, Braibant M, Jourdain G, Moreau A, Ngo-Giang-Huong N, Leechanachai P, Hemvuttiphan J, Hinjiranandana T, Changchit T, Warachit B, et al: Characteristics of HIV type 1 (HIV-1) glycoprotein 120 env sequences in mother-infant pairs infected with HIV-1 subtype CRF01_AE. J Infect Dis 2008, 198:868-876.

86. Zhang H, Tully DC, Hoffmann FG, He J, Kankasa C, Wood C: Restricted genetic diversity of HIV-1 subtype $C$ envelope glycoprotein from perinatally infected Zambian infants. PLoS One 2010, 5:e9294.

87. Kishko M, Somasundaran M, Brewster F, Sullivan JL, Clapham PR, Luzuriaga K: Genotypic and functional properties of early infant HIV-1 envelopes. Retrovirology 2011, 8:67.

88. Russell ES, Kwiek JJ, Keys J, Barton K, Mwapasa V, Montefiori DC, Meshnick SR, Swanstrom R: The genetic bottleneck in vertical transmission of subtype $C$ HIV-1 is not driven by selection of especially neutralization-resistant virus from the maternal viral population. J Virol 2011, 85:8253-8262.

89. Fouda GG, Mahlokozera T, Salazar-Gonzalez JF, Salazar MG, Learn G, Kumar SB, Dennison SM, Russell E, Rizzolo K, Jaeger F, et al: Postnatallytransmitted HIV-1 envelope variants have similar neutralizationsensitivity and function to that of nontransmitted breast milk variants. Retrovirology 2013, 10:3.

90. Gantt S, Carlsson J, Heath L, Bull ME, Shetty AK, Mutsvangwa J, Musingwini G, Woelk G, Zijenah LS, Katzenstein DA, et al: Genetic analyses of HIV-1 env sequences demonstrate limited compartmentalization in breast milk and suggest viral replication within the breast that increases with mastitis. J Virol 2010, 84:10812-10819.

91. Heath L, Conway S, Jones L, Semrau K, Nakamura K, Walter J, Decker WD, Hong J, Chen T, Heil M, et al: Restriction of HIV-1 genotypes in breast milk does not account for the population transmission genetic bottleneck that occurs following transmission. PLoS One 2010, 5:e10213.

92. Salazar-Gonzalez JF, Salazar MG, Learn GH, Fouda GG, Kang HH, Mahlokozera T, Wilks AB, Lovingood RV, Stacey A, Kalilani L, et al: Origin and evolution of HIV-1 in breast milk determined by single-genome amplification and sequencing. J Virol 2011, 85:2751-2763.

93. Chohan B, Lang D, Sagar M, Korber B, Lavreys L, Richardson B, Overbaugh J: Selection for human immunodeficiency virus type 1 envelope glycosylation variants with shorter V1-V2 loop sequences occurs during transmission of certain genetic subtypes and may impact viral RNA levels. J Virol 2005, 79:6528-6531.

94. Frost SD, Liu Y, Pond SL, Chappey C, Wrin T, Petropoulos CJ, Little SJ, Richman DD: Characterization of human immunodeficiency virus type 1 (HIV-1) envelope variation and neutralizing antibody responses during transmission of HIV-1 subtype B. J Virol 2005, 79:6523-6527.

95. Thenin S, Samleerat T, Tavernier E, Ngo-Giang-Huong N, Jourdain G, Lallemant M, Barin F, Braibant M: Envelope glycoproteins of human immunodeficiency virus type 1 variants issued from mother-infant pairs display a wide spectrum of biological properties. Virology 2012, 426:12-21.

96. Walker LM, Huber M, Doores KJ, Falkowska E, Pejchal R, Julien JP, Wang SK, Ramos A, Chan-Hui PY, Moyle M, et al: Broad neutralization coverage of HIV by multiple highly potent antibodies. Nature 2011 , 477:466-470

97. Moore PL, Gray ES, Wibmer CK, Bhiman JN, Nonyane M, Sheward DJ, Hermanus T, Bajimaya S, Tumba NL, Abrahams MR, et al: Evolution of an HIV glycan-dependent broadly neutralizing antibody epitope through immune escape. Nat Med 2012, 18:1688-1692.

98. Scarlatti G, Leitner T, Hodara V, Halapi E, Rossi P, Albert J, Fenyo EM: Neutralizing antibodies and viral characteristics in mother-to-child transmission of HIV-1. AIDS 1993, 7(Suppl 2):S45-48.

99. Scarlatti G, Albert J, Rossi P, Hodara V, Biraghi P, Muggiasca L, Fenyo EM: Mother-to-child transmission of human immunodeficiency virus type 1 : correlation with neutralizing antibodies against primary isolates. $J$ Infect Dis 1993, 168:207-210

100. Bongertz V, Costa Cl, Veloso VG, Grinsztejn B, Filho EC, Calvet G, Pilotto JH: Neutralization titres and vertical HIV-1 transmission. Scand J Immunol 2002, 56:642-644.

101. Bongertz V, Costa Cl, Veloso VG, Grinsztejn B, Joao Filho EC, Calvet G, Pilotto $\mathrm{JH}$, Guimaraes ML, Morgado MG: Vertical HIV-1 transmission: importance of neutralizing antibody titer and specificity. Scand J Immunol 2001, 53:302-309.

102. Kliks SC, Wara DW, Landers DV, Levy JA: Features of HIV-1 that could influence maternal-child transmission. Jama 1994, 272:467-474.

103. Zhang H, Rola M, West JT, Tully DC, Kubis P, He J, Kankasa C, Wood C: Functional properties of the HIV-1 subtype $C$ envelope glycoprotein associated with mother-to-child transmission. Virology 2010, 400:164-174.

104. Mabondzo A, Narwa R, Roques P, Gras GS, Herve F, Parnet-Mathieu F, Lasfargues G, Courpotin C, Dormont D: Lack of correlation between vertical transmission of HIV-1 and maternal antibody titers against autologous virus in human monocyte-derived macrophages. J Acquir Immune Defic Syndr Hum Retrovirol 1998, 17:92-94.

105. Hengel RL, Kennedy MS, Steketee RW, Thea DM, Abrams EJ, Lambert G, McDougal JS: Neutralizing antibody and perinatal transmission of human immunodeficiency virus type 1. New York city perinatal HIV transmission collaborative study group. AIDS Res Hum Retroviruses 1998, 14:475-481.

106. Baan E, de Ronde A, Stax M, Sanders RW, Luchters S, Vyankandondera J, Lange JM, Pollakis G, Paxton WA: HIV-1 autologous antibody neutralization associates with mother to child transmission. PLOS One 2013, 8:e69274.

107. Barin F, Jourdain G, Brunet S, Ngo-Giang-Huong N, Weerawatgoompa S, Karnchanamayul W, Ariyadej S, Hansudewechakul R, Achalapong J, Yuthavisuthi $P$, et al: Revisiting the role of neutralizing antibodies in mother-to-child transmission of HIV-1. J Infect Dis 2006, 193:1504-1511.

108. Samleerat T, Thenin S, Jourdain G, Ngo-Giang-Huong N, Moreau A, Leechanachai $P$, Ithisuknanth J, Pagdi K, Wannarit P, Sangsawang S, et al: Maternal neutralizing antibodies against a CRF01_AE primary isolate are associated with a low rate of intrapartum HIV-1 transmission. Virology 2009, 387:388-394.

109. Chaillon A, Wack T, Braibant M, Mandelbrot L, Blanche S, Warszawski J, Barin F: The breadth and titer of maternal HIV-1-specific heterologous 
neutralizing antibodies are not associated with a lower rate of motherto-child transmission of HIV-1. J Virol 2012, 86:10540-10546.

110. Lynch JB, Nduati R, Blish CA, Richardson BA, Mabuka JM, Jalalian-Lechak Z, John-Stewart G, Overbaugh J: The breadth and potency of passively acquired human immunodeficiency virus type 1-specific neutralizing antibodies do not correlate with the risk of infant infection. J Virol 2011, 85:5252-5261

111. Diomede L, Nyoka S, Pastori C, Scotti L, Zambon A, Sherman G, Gray CM, Sarzotti-Kelsoe M, Lopalco L: Passively transmitted gp41 antibodies in babies born from HIV-1 subtype C-seropositive women: correlation between fine specificity and protection. J Virol 2012, 86:4129-4138.

112. Walker LM, Simek MD, Priddy F, Gach JS, Wagner D, Zwick MB, Phogat SK, Poignard P, Burton DR: A limited number of antibody specificities mediate broad and potent serum neutralization in selected HIV-1 infected individuals. PLoS Pathog 2010, 6:e1001028.

113. Stamatatos L, Morris L, Burton DR, Mascola JR: Neutralizing antibodies generated during natural HIV-1 infection: good news for an HIV-1 vaccine? Nat Med 2009, 15:866-870.

114. Gray ES, Taylor N, Wycuff D, Moore PL, Tomaras GD, Wibmer CK, Puren A, DeCamp A, Gilbert PB, Wood B, et al: Antibody specificities associated with neutralization breadth in plasma from human immunodeficiency virus type 1 subtype C-infected blood donors. J Virol 2009, 83:8925-8937.

115. Corti D, Langedijk JP, Hinz A, Seaman MS, Vanzetta F, Fernandez-Rodriguez BM, Silacci C, Pinna D, Jarrossay D, Balla-Jhagjhoorsingh S, et al: Analysis of memory $B$ cell responses and isolation of novel monoclonal antibodies with neutralizing breadth from HIV-1-infected individuals. PLoS One 2010, 5:e8805.

116. Walker LM, Phogat SK, Chan-Hui PY, Wagner D, Phung P, Goss JL, Wrin T, Simek MD, Fling S, Mitcham JL, et al: Broad and potent neutralizing antibodies from an African donor reveal a new HIV-1 vaccine target. Science 2009, 326:285-289.

117. Wu X, Yang ZY, Li Y, Hogerkorp CM, Schief WR, Seaman MS, Zhou T, Schmidt SD, Wu L, Xu L, et al: Rational design of envelope identifies broadly neutralizing human monoclonal antibodies to HIV-1. Science 2010, 329:856-861.

118. Burton DR, Poignard P, Stanfield RL, Wilson IA: Broadly neutralizing antibodies present new prospects to counter highly antigenically diverse viruses. Science 2012, 337:183-186.

119. Raux M, Finkielsztejn L, Salmon-Ceron D, Bouchez H, Excler JL, Dulioust E, Grouin JM, Sicard D, Blondeau C: Comparison of the distribution of lgG and IgA antibodies in serum and various mucosal fluids of HIV type 1infected subjects. AIDS Res Hum Retroviruses 1999, 15:1365-1376.

120. Mestecky J, Jackson S, Moldoveanu Z, Nesbit LR, Kulhavy R, Prince SJ, Sabbaj S, Mulligan MJ, Goepfert PA: Paucity of antigen-specific IgA responses in sera and external secretions of HIV-type 1-infected individuals. AIDS Res Hum Retroviruses 2004, 20:972-988.

121. Van de Perre P: Transfer of antibody via mother's milk. Vaccine 2003, 21:3374-3376

122. Fouda GG, Yates NL, Pollara J, Shen X, Overman GR, Mahlokozera T, Wilks $A B$, Kang HH, Salazar-Gonzalez JF, Salazar MG, et al: HIV-specific functional antibody responses in breast milk mirror those in plasma and are primarily mediated by IgG antibodies. J Virol 2011, 85:9555-9567.

123. Permar SR, Wilks AB, Ehlinger EP, Kang HH, Mahlokozera T, Coffey RT, Carville A, Letvin NL, Seaman MS: Limited contribution of mucosal IgA to simian immunodeficiency virus (SIV)-specific neutralizing antibody response and virus envelope evolution in breast milk of SIV-infected, lactating rhesus monkeys. J Virol 2010, 84:8209-8218.

124. Williams SB, Flanigan TP, Cu-Uvin S, Mayer K, Williams P, Ettore CA, Artenstein AW, Duerr A, VanCott TC: Human immunodeficiency virus (HIV)-specific antibody in cervicovaginal lavage specimens obtained from women infected with HIV type 1. Clin Infect Dis 2002, 35:611-617.

125. Lu FX: Predominate HIV1-specific IgG activity in various mucosal compartments of HIV1-infected individuals. Clin Immunol 2000, 97:59-68

126. Haimovici F, Mayer KH, Anderson DJ: Quantitation of HIV-1-specific lgG, $\lg \mathrm{A}$, and $\lg \mathrm{M}$ antibodies in human genital tract secretions. J Acquir Immune Defic Syndr Hum Retrovirol 1997, 15:185-191.

127. Fiore JR, Laddago V, Lepera A, La Grasta L, Di Stefano M, Saracino A, Lopalco P, Pastore G, Angarano G: Limited secretory-IgA response in cervicovaginal secretions from HIV-1 infected, but not high risk seronegative women: lack of correlation to genital viral shedding. New Microbiol 2000, 23:85-92.
128. Belec L, Ghys PD, Hocini H, Nkengasong JN, Tranchot-Diallo J, Diallo MO, Ettiegne-Traore V, Maurice C, Becquart P, Matta M, et al: Cervicovaginal secretory antibodies to human immunodeficiency virus type 1 (HIV-1) that block viral transcytosis through tight epithelial barriers in highly exposed HIV-1-seronegative African women. J Infect Dis 2001, 184:1412-1422.

129. Rychert J, Amedee AM: The antibody response to SIV in lactating rhesus macaques. J Acquir Immune Defic Syndr 2005, 38:135-141.

130. Kuhn L, Trabattoni D, Kankasa C, Sinkala M, Lissoni F, Ghosh M, Aldrovandi G, Thea D, Clerici M: Hiv-specific secretory IgA in breast milk of HIVpositive mothers is not associated with protection against HIV transmission among breast-fed infants. J Pediatr 2006, 149:611-616.

131. Becquart P, Hocini H, Levy M, Sepou A, Kazatchkine MD, Belec L: Secretory anti-human immunodeficiency virus (HIV) antibodies in colostrum and breast milk are not a major determinant of the protection of early postnatal transmission of HIV. J Infect Dis 2000, 181:532-539.

132. Mabuka J, Nduati R, Odem-Davis K, Peterson D, Overbaugh J: HIV-specific antibodies capable of ADCC are common in breastmilk and are associated with reduced risk of transmission in women with high viral loads. PLoS Pathog 2012, 8:e1002739.

133. Bomsel M, Tudor D, Drillet AS, Alfsen A, Ganor Y, Roger MG, Mouz N, Amacker M, Chalifour A, Diomede L, et al: Immunization with HIV-1 gp41 subunit virosomes induces mucosal antibodies protecting nonhuman primates against vaginal SHIV challenges. Immunity 2011, 34:269-280.

134. Watkins JD, Sholukh AM, Mukhtar MM, Siddappa NB, Lakhashe SK, Kim M, Reinherz EL, Gupta S, Forthal DN, Sattentau QJ, et al: Anti-HIV IgA isotypes: differential virion capture and inhibition of transcytosis are linked to prevention of mucosal R5 SHIV transmission. AIDS 2013, 27:F13-20.

135. Roben P, Moore JP, Thali M, Sodroski J, Barbas CF 3rd, Burton DR: Recognition properties of a panel of human recombinant Fab fragments to the CD4 binding site of gp120 that show differing abilities to neutralize human immunodeficiency virus type 1. J Virol 1994, 68:4821-4828.

136. Thali M, Olshevsky U, Furman C, Gabuzda D, Posner M, Sodroski J: Characterization of a discontinuous human immunodeficiency virus type 1 gp120 epitope recognized by a broadly reactive neutralizing human monoclonal antibody. J Virol 1991, 65:6188-6193.

137. Trkola A, Purtscher M, Muster T, Ballaun C, Buchacher A, Sullivan N, Srinivasan K, Sodroski J, Moore JP, Katinger H: Human monoclonal antibody $2 \mathrm{G} 12$ defines a distinctive neutralization epitope on the gp120 glycoprotein of human immunodeficiency virus type 1. J Virol 1996, 70:1100-1108

138. Muster T, Steindl F, Purtscher M, Trkola A, Klima A, Himmler G, Ruker F, Katinger $\mathrm{H}$ : A conserved neutralizing epitope on gp41 of human immunodeficiency virus type 1. J Virol 1993, 67:6642-6647.

139. Zwick MB, Labrijn AF, Wang M, Spenlehauer C, Saphire EO, Binley JM, Moore JP, Stiegler G, Katinger H, Burton DR, Parren PW: Broadly neutralizing antibodies targeted to the membrane-proximal external region of human immunodeficiency virus type 1 glycoprotein gp41. J Virol 2001, 75:10892-10905.

140. Li J, Lord Cl, Haseltine W, Letvin NL, Sodroski J: Infection of cynomolgus monkeys with a chimeric HIV-1/SIVmac virus that expresses the HIV-1 envelope glycoproteins. J Acquir Immune Defic Syndr 1992, 5:639-646.

141. Luciw PA, Pratt-Lowe E, Shaw KE, Levy JA, Cheng-Mayer C: Persistent infection of rhesus macaques with T-cell-line-tropic and macrophagetropic clones of simian/human immunodeficiency viruses (SHIV). Proc Natl Acad Sci USA 1995, 92:7490-7494.

142. Shibata R, Kawamura M, Sakai H, Hayami M, Ishimoto A, Adachi A: Generation of a chimeric human and simian immunodeficiency virus infectious to monkey peripheral blood mononuclear cells. J Virol 1991, 65:3514-3520.

143. Sakuragi S, Shibata R, Mukai R, Komatsu T, Fukasawa M, Sakai H, Sakuragi J, Kawamura M, lbuki K, Hayami M, et al: Infection of macaque monkeys with a chimeric human and simian immunodeficiency virus. J Gen Virol 1992, 73(Pt 11):2983-2987.

144. Ranjbar S, Jones S, Stott EJ, Almond N: The construction and evaluation of SIV/HIV chimeras that express the envelope of European HIV type 1 isolates. AIDS Res Hum Retroviruses 1997, 13:797-800.

145. Reimann KA, Li JT, Voss G, Lekutis C, Tenner-Racz K, Racz P, Lin W, Montefiori DC, Lee-Parritz DE, Lu Y, et al: An env gene derived from a primary human immunodeficiency virus type 1 isolate confers high 
in vivo replicative capacity to a chimeric simian/human immunodeficiency virus in rhesus monkeys. J Virol 1996, 70:3198-3206.

146. Shibata R, Maldarelli F, Siemon C, Matano T, Parta M, Miller G, Fredrickson T, Martin MA: Infection and pathogenicity of chimeric simian-human immunodeficiency viruses in macaques: determinants of high virus loads and CD4 cell killing. J Infect Dis 1997, 176:362-373.

147. Jayaraman P, Zhu T, Misher L, Mohan D, Kuller L, Polacino P, Richardson BA, Bielefeldt-Ohmann H, Anderson D, Hu SL, Haigwood NL: Evidence for persistent, occult infection in neonatal macaques following perinatal transmission of simian-human immunodeficiency virus SF162P3. J Virol 2007, 81:822-834

148. Hofmann-Lehmann R, Vlasak J, Rasmussen RA, Smith BA, Baba TW, Liska V, Ferrantelli F, Montefiori DC, McClure HM, Anderson DC, et al: Postnatal passive immunization of neonatal macaques with a triple combination of human monoclonal antibodies against oral simian-human immunodeficiency virus challenge. J Virol 2001, 75:7470-7480.

149. Hofmann-Lehmann R, Vlasak J, Rasmussen RA, Jiang S, Li PL, Baba TW Montefiori DC, Bernacky BJ, Rizvi TA, Schmidt R, et al: Postnatal pre- and postexposure passive immunization strategies: protection of neonatal macaques against oral simian-human immunodeficiency virus challenge. J Med Primatol 2002, 31:109-119.

150. Ferrantelli F, Rasmussen RA, Buckley KA, Li PL, Wang T, Montefiori DC, Katinger H, Stiegler G, Anderson DC, McClure HM, Ruprecht RM: Complete protection of neonatal rhesus macaques against oral exposure to pathogenic simian-human immunodeficiency virus by human anti-HIV monoclonal antibodies. J Infect Dis 2004, 189:2167-2173.

151. Ferrantelli F, Buckley KA, Rasmussen RA, Chalmers A, Wang T, Li PL, Williams AL, Hofmann-Lehmann R, Montefiori DC, Cavacini LA, et al: Time dependence of protective post-exposure prophylaxis with human monoclonal antibodies against pathogenic SHIV challenge in newborn macaques. Virology 2007, 358:69-78.

152. Huang J, Ofek G, Laub L, Louder MK, Doria-Rose NA, Longo NS, Imamichi H, Bailer RT, Chakrabarti B, Sharma SK, et al: Broad and potent neutralization of HIV-1 by a gp41-specific human antibody. Nature 2012, 491:406-412.

153. Diskin R, Scheid JF, Marcovecchio PM, West AP Jr, Klein F, Gao H, Gnanapragasam PN, Abadir A, Seaman MS, Nussenzweig MC, Bjorkman PJ: Increasing the potency and breadth of an HIV antibody by using structure-based rational design. Science 2011, 334:1289-1293.

154. Moldt B, Rakasz EG, Schultz N, Chan-Hui PY, Swiderek K, Weisgrau KL, Piaskowski SM, Bergman Z, Watkins DI, Poignard P, Burton DR: Highly potent HIV-specific antibody neutralization in vitro translates into effective protection against mucosal SHIV challenge in vivo. Proc Natl Acad Sci USA 2012, 109:18921-18925.

155. Klein F, Halper-Stromberg A, Horwitz JA, Gruell H, Scheid JF, Bournazos S, Mouquet H, Spatz LA, Diskin R, Abadir A, et al: HIV therapy by a combination of broadly neutralizing antibodies in humanized mice. Nature 2012, 492:118-122.

156. Ng CT, Jaworski JP, Jayaraman P, Sutton WF, Delio P, Kuller L, Anderson D, Landucci G, Richardson BA, Burton DR, et al: Passive neutralizing antibody controls SHIV viremia and enhances $B$ cell responses in infant macaques. Nat Med 2010, 16:1117-1119.

157. Shetty AK, Maldonado Y: Antiretroviral drugs to prevent mother-to-child transmission of HIV during breastfeeding. Curr HIV Res 2013, 11:102-125.

158. Mofenson LM: Prevention of mother-to-child HIV-1 transmission-why we still need a preventive HIV immunization strategy. J Acquir Immune Defic Syndr 2011, 58:359-362.

159. Stiehm ER, Lambert JS, Mofenson LM, Bethel J, Whitehouse J, Nugent R, Moye J Jr, Glenn Fowler M, Mathieson BJ, Reichelderfer P, et al: Efficacy of zidovudine and human immunodeficiency virus (HIV) hyperimmune immunoglobulin for reducing perinatal HIV transmission from HIVinfected women with advanced disease: results of pediatric AIDS clinical trials group protocol 185. J Infect Dis 1999, 179:567-575.

160. Onyango-Makumbi C, Omer SB, Mubiru M, Moulton LH, Nakabiito C, Musoke P, Mmiro F, Zwerski S, Wigzell H, Falksveden L, et al: Safety and efficacy of HIV hyperimmune globulin for prevention of mother-to-child HIV transmission in HIV-1-infected pregnant women and their infants in Kampala, Uganda (HIVIGLOB/NVP STUDY). J Acquir Immune Defic Syndr 2011, 58:399-407.

161. Xu W, Hofmann-Lehmann R, McClure HM, Ruprecht RM: Passive immunization with human neutralizing monoclonal antibodies: correlates of protective immunity against HIV. Vaccine 2002, 20:1956-1960.
162. Safrit JT, Ruprecht R, Ferrantelli F, Xu W, Kitabwalla M, Van Rompay K, Marthas M, Haigwood N, Mascola JR, Luzuriaga K, et al: Immunoprophylaxis to prevent mother-to-child transmission of HIV-1. J Acquir Immune Defic Syndr 2004, 35:169-177.

163. Gray ES, Meyers T, Gray G, Montefiori DC, Morris L: Insensitivity of paediatric HIV-1 subtype $C$ viruses to broadly neutralising monoclonal antibodies raised against subtype B. PLoS Med 2006, 3:e255.

164. Russell ES, Ojeda S, Fouda GG, Meshnick SR, Montefiori D, Permar SR, Swanstrom R: Short communication: HIV type 1 subtype $C$ variants transmitted through the bottleneck of breastfeeding are sensitive to new generation broadly neutralizing antibodies directed against quaternary and CD4-binding site epitopes. AIDS Res Hum Retroviruses 2013, 29:511-515

165. Nakamura KJ, Cerini C, Sobrera ER, Heath L, Sinkala M, Kankasa C, Thea DM, Mullins JI, Kuhn L, Aldrovandi GM: Coverage of primary mother-to-child HIV transmission isolates by second-generation broadly neutralizing antibodies. AIDS 2013, 27:337-346.

166. Mabuka J, Goo L, Omenda MM, Nduati R, Overbaugh J: HIV-1 maternal and infant variants show similar sensitivity to broadly neutralizing antibodies, but sensitivity varies by subtype. AIDS 2013, 27:1535-1544.

167. Editorial: prevention measures. Nat Med 2013, 19:247.

\section{doi:10.1186/1742-4690-10-103}

Cite this article as: Braibant and Barin: The role of neutralizing antibodies in prevention of HIV-1 infection: what can we learn from the mother-to-child transmission context?. Retrovirology 2013 10:103.

\section{Submit your next manuscript to BioMed Central and take full advantage of:}

- Convenient online submission

- Thorough peer review

- No space constraints or color figure charges

- Immediate publication on acceptance

- Inclusion in PubMed, CAS, Scopus and Google Scholar

- Research which is freely available for redistribution

Submit your manuscript at www.biomedcentral.com/submit
C) Biomed Central 